\title{
Infotainment, Sinetron dan Sinisme Ibu Rumah Tangga "Mengapa Ibu Rumah Tangga Menggemarinya?" (Analisis Berdasarkan Cultivation Theory)
}

\author{
Vigor Wirayodha Hendriwinaya ${ }^{1}$ \\ Program Magister Psikologi \\ Fakultas Psikologi Universitas Gadjah Mada
}

\section{Pengantar}

Hiburan yang murah, mudah, dan dekat menjadi pilihan bagi masyarakat. Menonton acara televisi adalah salah satu diantaranya. Cukup dengan membeli televisi masyarakat sudah dapat menikmati program-program acara yang ditawarkan. Stasiun televisi barupun marak bermunculan, mulai dari televisi yang dapat diakses melalui antena UHF/VHF atau melalui dekoder/ TV kabel berlangganan. Berdasarkan survei Nielsen Audience Measurement pada tahun 2012, bahwa 94\% masyarakat Indonesia mencari informasi dan hiburan melalui televisi (www.tempo.co).

Persaingan yang kompetitif diantara stasiun televisi membuat stasiun televisi harus memiliki program-program yang menarik bagi masyarakat, seperti: berita, sajian debat, talk show, diskusi (informatifedukatif), kuis, film, sinetron, infotainment, reality show, acara musik (entertainment), serta dakwah agama, siraman rohani (religi). Program-program tersebut menjadi unggulan bagi stasiun televisi untuk menjaga rating dan eksistensinya dalam dunia pertelevisian.Program unggulan adalah program terpenting dalam menjaga rating stasiun televisi. Program unggulan biasa-

\footnotetext{
1 Koresponsdensi mengenai isi artikel ini dapat melalui: vigor.wirayodha@mail.ugm.ac.id
}

nya mengadopsi dari program acara luar negeri seperti dari Fremantle Media Enterprises (sebuah perusahaan internasional yang menjual lisensi programprogram acara seperti kuis, reality show, dan kompetisi) atau asli buatan dari production house stasiun televisi itu sendiri. Contoh program unggulan: RCTI, "tukang bubur naik haji" dan "X-Factor." TV ONE, "Indonesia Lawyers Club". SCTV, "INBOX" dan "eat bulaga". Trans TV, "Indonesia Mencari Bakat", program-progam unggulan tersebut disusun secara serius dengan kualitas yang baik.

Selain mengeluarkan program-program unggulan, stasiun televisi juga mengeluarkan program pendukung untuk menambah rating pemirsa. Sinetron dan infotainment termasuk dalam beberapa program pendukung. Sinetron adalah singkatan dari sinema elektronik, yakni sebuah film seri yang ditayangkan melalui televisi (Hasnawati, 2013). Sinetron pada umumnya bercerita tentang kehidupan manusia sehari-hari yang diwarnai konflik. Infotainment adalah gabungan kata informasi dan entertainment, informasi yang dikemas dengan cara yang menghibur. Informasi yang disampaikan kepada pemirsa bukanlah informasi yang mereka butuhkan, tetapi informasi yang dianggap dapat menghibur (Iswandi, 2006). 
Beberapa sinetron yang terdapat pada program televisi di tahun 2013: RCTI, "Tukang bubur Naik Haji". SCTV, "Ustadz Fotocopy", "Pesantren dan Rock n' Roll”, "Heart Series 2". MNCTV, "Raden Kian Santang", "Tendangan Si Madun". Trans TV, "Cinta Cenat Cenut, "SM*SH". Global TV, "Kinara". Dan lainlain. Beberapa infotainment yang terdapat pada program televisi: RCTI, "Intens", "Go Spot", "Cek \& Ricek", "Silet", dan "Kabar Kabari". SCTV, "Hot Shot", "Halo Selebriti", "Status Selebriti", dan "Was Was", Global TV, "Insert Pagi", "Insert", "Insert Investigasi". Dan lain-lain. Beberapa sinetron dan infotainment adalah program pendukung, walaupun pada proses penyusunannya dilakukan secara serius namun relevansi dan kualitas dari informasi serta edukasi di dalamnya kurang.

\section{Infotainment sebuah bisnis besar yang dikritik}

Infotainment memiliki porsi sekitar $10 \%$ dalam program televisi setiap harinya (Ahmadi, 2005). Berdasarkan survei yang dilakukan di sebuah daerah, didapatkan hasil bahwa penonton infotainment adalah $73 \%$ perempuan dan $46,25 \%$ ibu rumah tangga (Sukarelawati, 2009). Berdasarkan pasar yang ada infotainment beralih menjadi industri hiburan, dimana kehidupan sehari-hari artis adalah objek yang menarik untuk "dijual". Berdasarkan pantauan Komisi Penyiaran Indonesia (KPI) (Ahmadi, 2005), pada Agustus 2005, dalam satu hari terdapat 13 jam penayangan infotainment dalam program televisi.

Berdasarkan pembagian jam tayang Prime Time (19.00-23.00), Late Fringe Time, All other Time (01.00-10.00), Day Time (10.00-16.30), dan Fringe Time (16.00-19.30). Pada umumnya infotainment berada pada pukul 07.00, 09.00, 15.00, dan 16.00 WIB (All other Time-Fringe Time), tidak ada yang berada pada Prime Time (Ahmadi, 2005).
Penayangan infotainment diluar jam Prime Time menghemat biaya yang harus ditanggung oleh stasiun televisi.

Ahmadi (2005) mencoba mengkalkulasi pendapatan stasiun televisi melalui program infotainment, rata-rata adalah sebesar Rp 25 juta per episode adalah uang yang harus dikeluarkan oleh stasiun televisi untuk membeli program infotainment. Perkiraan pendapatan iklan yang terdapat selama waktu program tersebut berjalan adalah sebesar Rp 60 juta, ada selisih Rp 35 juta yang merupakan pendapatan dari program infotainment per episode. Stasiun televisi biasa menayangkan dua hingga empat infotainment dalam sehari. Diperkirakan satu hingga tiga miliar rupiah per tahun bisa didapatkan stasiun televisi dari program ini.

Disamping memberi pemasukan yang besar bagi stasiun televisi, infotainment juga menuai banyak kritikan. Nahdatul Ulama (NU) telah mengeluarkan keputusan bahwa berita infotainment yang mencampur adukkan rahasia keluarga merupakan larangan keras agama (www.beritasore.com). Dijelaskan bahwa dampak infotainment cenderung membiasakan masyarakat untuk melihat kesalahan-kesalahan orang lain, dibandingkan dengan mengintrospeksi diri. Majelis Ulama Indonesia (MUI) Sumatera Utara telah mensosialisasikan fatwa haram terhadap infotainment yang tercantum surat Komisi Fatwa MUI Pusat Tahun 2010 (www.nu.or.id). Pada akhir tahun 2010 salah satu program infotainment (Silet) terjerat kasus hukum terkait pemberitaan bahwa Yogyakarta adalah kota malapetaka dan pada tanggal 8 November 2010 akan terjadi bencana besar (www. entertainment.kompas.com). Infotainment sebagai media informasi yang menghibur menuai banyak kontroversi, dimana informasi yang disampaikan seringkali mence- 
ritakan aib orang lain dan cenderung melebih-lebihkan.

\section{Sinetron sebagai proses pemikiran utopia}

Tampilan paket sinetron televisi mempunyai beberapa unsur yaitu cerita sinetron umumnya sesuai dengan realitas kehidupan masyarakat dan isi sinetron mengkomunikasikan soal pembangunan fisik maupun mental. Ada beberapa faktor yang membuat paket sinetron disukai, yaitu isi pesannya sesuai dengan realitas sosial pemirsa, isi pesannya mengandung cerminan tradisi nilai luhur dan budaya pemirsa, dan isi pesannya lebih banyak mengangkat permasalahan atau persoalan yang terjadi dalam kehidupan masyarakat (Kuswandi, 1996).

Salah satu jenis sinetron adalah drama. Berbagai bentuk interaksi manusia baik pergaulan biasa, hubungan cinta, kerja sama, kontrak bisnis, hubungan kerja, perlombaan, persaingan, permusuhan baik yang mencerminkan saling pengertian maupun yang mencerminkan salah pengertian dikemas dalam berbagai bentuk drama televisi, baik komedi maupun tragedi (Radikun, 1995).

Kemasan sinetron semacam ini memungkinkan bagi pemirsa untuk merasakan bahwa kejadian-kejadian dalam sinetron signifikan dengan realita hidup. Shrum dkk. (1991) dalam penelitiannya, mengatakan bahwa pengalaman individu yang didapatkan dari menonton televisi akan berpengaruh terhadap proses pembuatan keputusan dan pertimbangan, dimana individu merasa bahwa apa yang mereka tonton adalah sesuai dengan realitas sosial mereka dalam kehidupan nyata.

Ang (2007) melakukan penelitian terkait persepsi pemirsa sinetron "Dallas" (drama televisi Amerika berseri yang populer pada tahun 1978), banyak pemirsa wanita melakukan identifikasi imajinasi melodramatis, yaitu mengadopsi perasaan-perasaan yang tergambar pada drama tersebut, merasa bahwa hal tersebut terjadi pada diri mereka. Hal tersebut terlihat dari sikap sentimentil yang berlebihan. Beberapa wanita menyukai drama ini karena mampu menghanyutkan perasaan. Beberapa kritikus TV mengatakan bahwa pertimbangan estetik yang berlebihan dari pemirsa "Dallas" mengabaikan masalah kualitas dari film itu sendiri. Nampaknya keterhanyutan emosi pada drama menjadi kesenangan sendiri bagi beberapa orang walaupun hal tersebut belum pasti sesuai dengan keadaan mereka di dunia nyata.

Ang (2007) juga menyikapi kemunculan drama televisi Asia Timur di tahun 1990. Pada waktu itu biasa disebut dengan "drama trendi", dimana perkembangan mode, aktris dan aktor yang cantik dan tampan, serta miniseri berorientasi remaja yang umumnya bercerita tentang hubungan romantis dikalangan profesional muda perkotaan kontemporer menjadi kesenangan baru bagi pemirsa drama televisi, seperti Tokyo Love Story. Demikian juga Indonesia memiliki sinetron "Tersanjung". Sinetron yang ditayangkan dari tahun 1998-2005 dengan lebih dari 360 episode ini, menyajikan drama percintaan dengan setting kehidupan mewah. Sinetron semacam ini mampu membangun dunia sosial tersendiri yang membawa pemikiran pemirsa kepada utopisme. (Thornham \& Purvis, 2005 dalam The CCS 2010 Conference and The 4th International Conference on Digital Communication, CHIA-YI, 2010) Setting kehidupan sosial yang mewah menjadi keinginan yang besar akan kualitas dan kesempurnaan, yang sering kali berbeda dengan kenyataan sosial pemirsa. 
Infotainment dan Sinetron membentuk Sinisme Ibu Rumah Tangga

Ibu rumah tangga yang tidak bekerja biasanya lebih banyak menghabiskan waktunya di rumah, untuk merawat dan mengasuh anak sesuai dengan pola-pola yang diberikan masyarakat (Dwijayanti 1999 dalam Mumtahinnah, 2008). Ketersediaan waktu di rumah yang lebih banyak pada ibu rumah tangga memungkinkan mereka untuk menonton televisi lebih sering, dan program acara televisi yang terbanyak ditonton adalah infotainment dan sinetron.

Dalam aktivitas kesehariannya memungkinkan ibu rumah tangga untuk berinteraksi dengan ibu rumah tangga lainnya. Pertemuan mereka bisa terjadi pada saat berbelanja, membersihkan halaman, arisan atau pada saat-saat lain dimana mereka keluar rumah. Perbincangan dan aktivitas meng-gosip muncul dalam pertemuan ibu-ibu rumah tangga ini. Wert dan Salovey (2004), mengatakan gosip atau membicarakan keburukan orang lain muncul sebagai respon dari perbandingan sosial. Dimana adanya persepsi ketidakadilan atau perasaan cemburu, iri hati, dan kebencian memberi berkontribusi terhadap munculnya gosip. Infotainment adalah salah satu sumber relevan dari gosip, dimana topik pembicaraan negatif tentang artis menjadi bahan pembicaraan yang menarik bagi ibu-ibu rumah tangga. Sinetron juga dapat menjadi bahan gosip walau kurang relevan dengan kehidupan sehari-hari, namun cerita-cerita dalam tiap serinya menjadi topik yang menarik pula untuk dibicarakan.

Gavreliu, Cîmpean, dan Gavreliuc (2008) berpendapat munculnya sikap sinis adalah sebagai kurangnya tanggung jawab dan kerjasama, ketidakpercayaan pada lembaga dan anggotanya, keyakinan bahwa sesuatu telah ditakdirkan, harapan sosial kurang, dan keterlepasan dari publik. Vice (2010) mendefinisikan sinisme dalam dua hal, yaitu: pertama, sinisme pada dasarnya adalah sikap terhadap manusia dan dunia yang mereka ciptakan melalui institusi mereka; kedua, sinisme adalah pendirian atau sikap terhadap orang lain; dimana didalamnya terkandung unsur struktur persepsi, interpretasi, evaluasi dan harapan orang lain, dan dapat memengaruhi tindakan kita sendiri. Dapat disimpulkan bahwa sinisme merupakan sifat dasar manusia yang mengubah gosip menjadi kritikan terhadap orang lain yang merupakan bentuk pelepasan frustasi diri melalui struktur persepsi, interpretasi, evaluasi dan harapan orang yang ditujukan untuk keuntungan diri dengan memengaruhi orang lain melalui percakapan ringan.

Kegemaran mendengarkan aib orang lain dan cenderung menyukai pemberitaan yang dilebih-lebihkan atau biasa yang disebut dengan gosip, serta sentimentil dan kesenangan penghanyutan perasaan pertimbangan estetik berlebih yang menghiraukan kualitas cerita, yang membawa kesulitan membedakan realitas hidup dengan cerita film membawa pemikiran ibu rumah tangga pada sikap sinis.

\section{Pengaruh Program Televisi (infotainment dan} sinetron)

Berikut ini adalah beberapa penelitian tentang pengaruh program televisi. Ang (2007) dalam penelitiannya pengaruh dari penayangan sinetron "Dallas" ditemukan bahwa keterhanyutan emosi adalah suatu kesenangan bagi pemirsa wanita. Raghavan (2008) dalam penelitiannya menemukan bahwa ada proses memengaruhi budaya dan politik India, melalui tokoh "Tulsi" dalam Kyunki Saas Bhi Kabhi Bahu Thi (drama televisi India), dimana seorang wanita tersebut memperjuangkan 


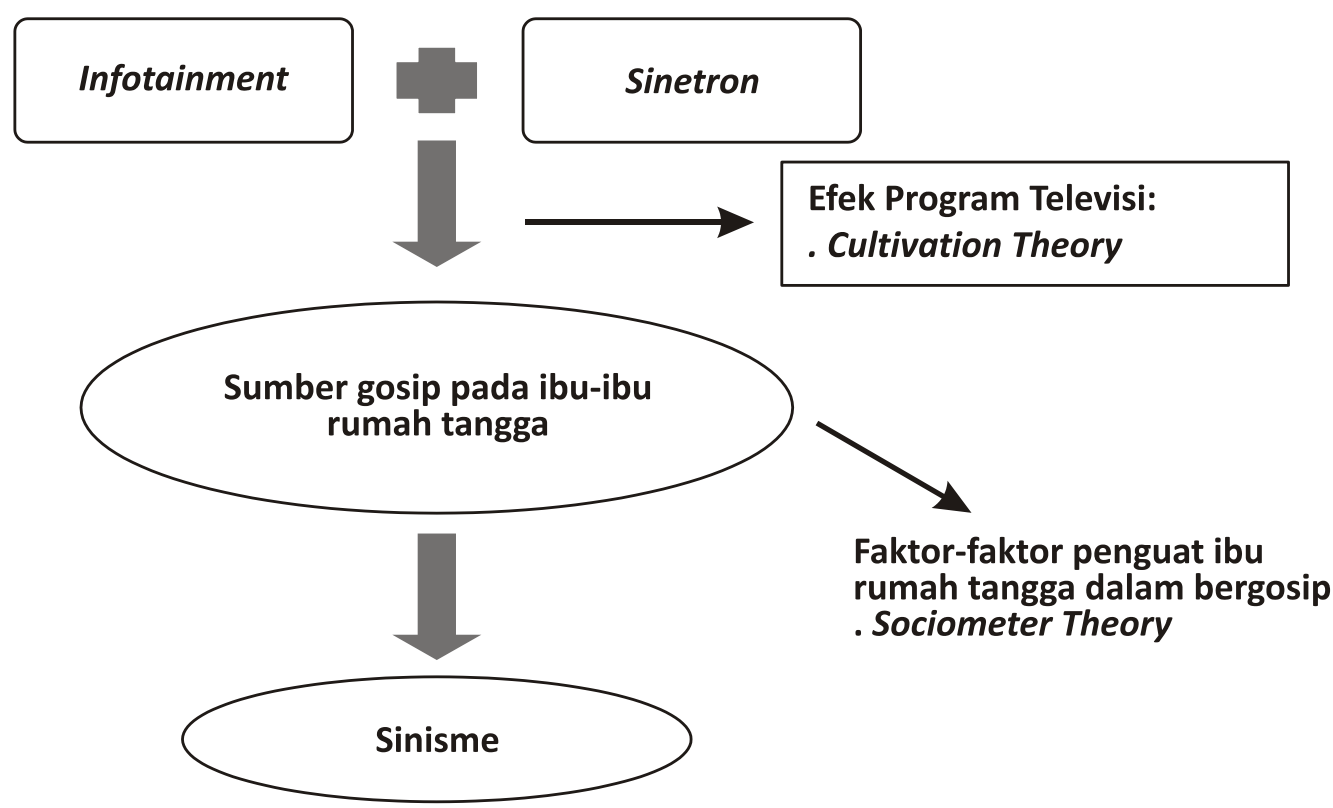

Gambar 1. Skema Analisis Pengaruh Program Televisi pada Ibu Rumah Tangga

relasi kekuasaan dalam sistem keluarga India. Hal ini menginspirasi banyak wanita India sekaligus dibenci oleh kaum lakilaki India.

Salah satu hasil penelitian yang didapat Auter dkk. (2010) adalah orang Mesir cenderung melihat sosok keluarga yang terdapat dalam drama televisi serupa dengan keluarga dalam kehidupan nyata, dibandingkan dengan orang Amerika. Hal ini mengindikasikan bias budaya pada persepsi akan pengaruh penayangan drama televisi.

Ashai (2013) menyimpulkan bahwa sinetron memiliki dampak yang mendalam pada gadis remaja. Seperti halnya pada faktor: body image, fashion, persepsi masa depan, kehidupan berkeluarga dan berkarir, penyadaran terhadap masalahmasalah sosial, dan motivasi untuk partisipasi dalam drama, musik dan kegiatan petualangan.

Berdasarkan hasil-hasil penelitian tersebut, penulis melakukan analisis pengaruh program televisi berupa infotainment dan sinetron berdasarkan Cultivation
Theory. Skema analisis pengaruh program televisi pada Ibu rumah tangga terlihat pada Gambar 1. Gerbner (1998) mendefinisikan kultivasi sebagai kontribusi independen menonton televisi membuat konsepsi pemirsa pada realitas sosial. Kultivasi menunjukkan bahwa pengaruh media yang terbangun melalui melihat dari waktu ke waktu, melihat berulangulang. Sehingga dapat dikatakan, pemirsa televisi cenderung melihat dunia nyata sesuai dengan apa yang mereka telah dilihat di televisi.

Pengolahan heuristik dan aksesibilitas adalah ide utama yang telah dikaitkan dengan kultivasi. Shrum dan Bischak (2001) mengamati bahwa orang sering membangun penilaian mereka pada kemungkinan terjadinya atas dasar atribut dari informasi yang mereka ambil dari memori. Ungkapan "pengolahan heuristik" menunjukkan bahwa orang cenderung untuk mencari sejumlah kecil informasi yang mudah diakses ketika membuat penilaian cepat, daripada secara sistematis mencari pada memori mereka (Shrum 
dalam Vonderen \& Kinnally, 2012). Konstruksi dan ide-ide yang sering diaktifkan menjadi lebih mudah diakses dari waktu ke waktu.

Unsur lain dari teori kultivasi adalah resonansi. Menurut Shrum dan Bischak (2001), resonansi adalah gagasan bahwa pengalaman hidup pemirsa memengaruhi persepsi mereka terhadap televisi. Jika pengalaman hidup pemirsa "mirip" dengan isi media yang mereka lihat, pesan media cenderung memiliki pengaruh pada mereka. Selain itu, kombinasi dari pengalaman membuat konten lebih mudah diakses (Shrum \& Bischak, 2001).

\section{Analisis}

Menonton infotainment dan sinetron dengan intesitas yang tinggi bisa memberi pengaruh tertentu pada ibu rumah tangga. Ibu rumah tangga cebderung mempersepsikan yang terjadi dalam tayangan televisi tersebut relevan dengan kehidupan nyata mereka. Hal ini akan diperkuat dengan kemiripan situasi-situasi dalam tayangan tersebut dengan realitas hidup mereka.

Informasi dan situasi negatif dalam tayangan tersebut akan memengaruhi ibu rumah tangga untuk bersikap negatif, seperti halnya sikap sinis. Dalam situasi tertentu ibu rumah tangga akan mengidentifikasi kejadian dalam kehidupan nyata bedasar sudut pandang pemberitaan buruk infotainment dan sinetron. Sebagai contoh, terkait pemberitaan seputar perselingkuhan di kalangan artis. Ibu rumah tangga akan cenderung lebih waspada, berpikiran negatif, dan bahkan bersikap berlebihan ketika mereka menemukan suaminya pulang larut malam. Contoh lain, gaya hidup seks bebas dalam cerita sinetron membentuk persepsi buruk pada kehidupan anak remaja mereka. Ibu rumah tangga akan menjadi over-protective, curiga kepada teman-teman anaknya, dan selalu was-was ketika anak lepas dari jangkauannya.

Penguatan pengaruh juga dapat terjadi dari kebiasaan ibu rumah tangga dalam bergosip. Sepertihalnya berbagi cerita tayangan televisi berlanjut hingga berbagi cerita kehidupan pribadi. Melalui kacamata yang sama ibu rumah tangga akan lebih mudah meyakinkan diri bahwa gosip yang mereka bahas adalah relevan dengan kehidupan, atau memiliki kecenderungan tinggi untuk terjadi. Terlebih jika ada kemiripan apa yang mereka gosipkan dengan realitas kehidupan.

Faktor-faktor Penguat Ibu Rumah Tangga dalam Bergosip

Sociometer theory. Menurut Hofstede (1983), budaya nasional Indonesia adalah budaya kolektif, dimana menjalin hubungan dekat dengan orang lain adalah hal yang penting. Pada budaya ini relasi interpersonal menjadi penting karena memengaruhi penerimaan dari orang lain. Menurut Triandis budaya kolektif membuka peluang hadirnya in-group dan outgroup, yang akan membawa pengaruh penting pada perilaku sosial (Buntaran, 2014). Sociometer theory menjelaskan bahwa individu memiliki kebutuhan untuk masuk dalam kelompok sosial dan harga diri adalah ukuran inklusi kesuksesan dan kepemilikan grup. Teori Sociometer berpendapat bahwa harga diri adalah suatu barometer yang individu dianggap menilai relasional masa lalu, sekarang, dan masa depan (Leary \& Baumeister, 2000). Anthony dkk (2005) menyebut konsep ini sebagai langkah antisipasi terhadap pengeluaran sosial, yang merupakan perhitungan bersih individu dari rewards, dikurangi biaya, dari berperilaku dengan cara tertentu dalam situasi sosial. Leary (2012) menyebutkan teori sociometer 


\section{HENDRIWINAYA}

berguna dalam pertahanan ego dan menghindari kecemasan.

\section{Analisis}

Beberapa ibu rumah tangga memiliki kebiasaan untuk berkumpul dan bercerita, baik secara khusus dalam satu kegiatan maupun kebetulan. Seperti halnya pada saat arisan, atau pertemuan dilingkungan tempat tinggal mereka. Ada kebutuhan kebutuhan untuk diterima oleh lingkungan sosial mereka atau sesama ibu rumah tangga. Salah satu indikator penerimaan tersebut adalah kemampuan mereka untuk menerima informasi-informasi yang aktual sebagai bahan perbincangan. Sumber-sumber penerimaan informasi itu dikhususkan pada infotainment dan sinetron. Ketika seorang ibu rumah tangga dapat berpartisipasi dalam perbincangan seputar infotainment dan sinetron atau dalam kata popular "nyambung", maka harga dirinya akan naik.

Pada teori sociometer disebutkan individu memiliki kebutuhan untuk masuk dalam kelompok sosial dan harga diri adalah ukuran inklusi kesuksesan dan kepemilikan grup. Keberadaan dan keterlibatan ibu rumah tangga dalam aktivitas perbincangan kelompok terdapat aktivitas meng-gosip. Pada kondisi tersebut ibu rumah tangga akan merasakan penerimaan kelompok, dirinya diangap penting untuk kontribusi kelompok, yang akhirnya memengaruhi harga diri dari ibu itu sendiri. Situasi seperti ini tidak mutlak benar, seperti yang terlihat dari penelitian Gavreliu, Cîmpean, dan Gavreliuc (2008) mengatakan tidak ada hubungan antara ketersediaan gosip dengan sikap sinis. Selain itu hasil lainnya mengatakan tidak ada korelasi antara kepuasaan hidup dengan sikap sinis. Pada penelitian tersebut ditemukan bahwa ada kemungkinan faktor pendidikan yang tinggi, menjalankan norma, dan cara pengungkapan diri yang baik mengurangi sikap sinis.

\section{Penutup}

Tayangan televisi berupa infotainment dan sinetron memengaruhi sikap dan persepsi ibu rumah tangga. Dimana ketika informasi yang didapat adalah negatif (salah satunya gosip) maka akan membentuk sikap sinis pada ibu rumah tangga. Pendidikan yang tinggi, menjalankan norma yang ada, dan mencari cara pengungkapan diri secara positif dapat membantu ibu rumah tangga dalam mengurangi sikap sinisme dari tayangan infotainment dan sinetron.

\section{Saran}

Ibu rumah tangga sebaiknya: (1) Memilih tayangan televisi secara bijak; (2) Menyadari bahwa infotainment dan sinetron adalah program hiburan bukan realitas kehidupan, dimana dramatisasi dan melankolisme adalah strategi stasiun televisi untuk "berjualan", dan terdapat banyak cara positif dalam pencapaian harga diri dalam relasi sosial.

Production House hendaknya membuat tayangan yang lebih berkualitas dan edukatif, strategi berjualan jangan sampai mengesampingkan norma dan moralitas.

Pemerintah dalam hal ini KPI seharusnya melakukan filterisasi dan mindak tegas Production House yang melanggar ketentuan perundang-undangan penyiaran. 


\section{Daftar Pustaka}

Ahmadi, D. (2005). “Quo Vadis Infotainment"? MediaTor, 9(1).

Ang, I. (2007). Television Fictions around the World: Melodrama and Irony in Global Perspective. Critical Studies in Television, 2(2), 18-30.

Anthony, D., Wood, J., \& Holmes, J. (2007). Testing sociometer theory: Self-esteem and the importance of acceptance for social decision-making. Journal of Experimental Social Psychology, 43, 425432.

Ashai, Y. (2013). Impact of Soap Operas on Adolescent Girls in Srinagar City. International Journal of Social Science Tomorrow, 2(1).

Auter, P., Agnihotri, I., Reda, M., Sharif, J., \& Roy, F. (2010). Effects of Viewing Drama on Egyptian and American Youths' Perceptions of Family. Diunduh dari: http://www2.gsu.edu/ $\sim$ wwwaus/Auter_Agnihoti_etal_JMEN _Submission_2nd_Revision.pdf

Bandura, A. (2012). Social Cognitive Theory. In L. Van Lange, A. W. Kruglanski, \& E. T. Higgins (Eds.), Handbook of theories of social psychology (Vol. 2, pp. 62-80). Los Angeles: Sage.

Berita Sore. (2010, 4 Agustus). Infotainment Lebih Banyak Sisi Negatif. Diunduh dari: http://beritasore.com/ 2010/08/04/infotainment-lebih-banyaksisi-negatif/ tanggal 19 April 2013.

Buntaran, F. A. A. (2014). Kaitan antara Kesepian dan Pengungkapan Diri yang Dimoderasi oleh Kepercayaan Interpersonal pada Pengguna Situs Jejaring Sosial Online. (Tesis tidak dipublikasikan). Yogyakarta: Fakultas Psikologi Universitas Gadjah Mada.
Gavreliu, A., Cîmpean, M., \& Gavreliuc, D. (2008). The "Availability to Gossip", Life Satisfaction and Social Cynicism among Romanians. Retrieved from http://alingavreliuc.files.wordpress.co m/2010/10/st-gavreliuc-d-a-campeanm-gosip-life-satisfaction-ans-socialcynicism-among-romaniansnovember-2008.pdf

Gerbner, G. (1998). Cultivation Analysis: An Overwiew. Mass Communication $\mathcal{E}$ Society, 1(3/4), 175-194.

Hasnawati. (2013). Dampak Menonton Tayangan Sinetron Putih Abu-Abu terhadap Perilaku Anak DI Kelurahan Sidodamai Samarinda: Studi Pada Adegan Aksi Bullying Dalam Sinetron Putih Abu-Abu di SCTV. eJournal llmu Komunikasi, 1(2), 126-137.

Hofstede, G. (1983). National Culture in Four Dimensions: A Research-Based Theory of Cultural Differences among Nations. International Studies of Management Organization. XIII(1-2), 46-74.

Iswandi, S. (2006). Jurnalistik Infotainment: Kancah Baru Jurnalistik Dalam Industri Televisi. Yogyakarta: Pilar Media.

Kompas.com. (2010, 8 November). Akui Salah Redaksi Silet Minta Maaf. Diunduh dari: http://entertainment. kompas.com/read/2010/11/08/03320851 /Akui.Salah..Redaksi.Silet.Minta.Maaf3 tanggal 19 April 2013.

Kuswandi, W. (1996). Komunikasi Massa Sebuah Analisis Media Televisi. Jakarta: Rhineka Cipta.

Leary, M. R. (2012). Sociometer Theory. In L. Van Lange, A. W. Kruglanski, \& E. T. Higgins (Eds.), Handbook of theories of social psychology (Vol. 2, pp. 141-159). Los Angeles: Sage.

Leary, M. R., \& Baumeister, R. F. (2000). The nature and function of selfesteem: 
Sociometer theory. In M. P. Zanna (Ed.), Advances in experimentalsocial psychology (Vol. 32, pp. 1-62). San Diego, CA: Academic Press.

Mumtahinnah, N. (2008). Hubungan antara Stres dengan Agresi pada Ibu Rumah Tangga yang Tidak Bekerja. Diunduh dari: http://www.gunadarma.ac.id/ library/articles/graduate/psychology/2 008/Artikel_10502173.pdf

Nu Online. (2006, 14 Desember). Tayangan Infotainment tentang Poligami Kebablasan., Diunduh dari: http://www. nu.or.id/a,public-m,dinamic-s, detailids,1-id,5680-lang,id-c,wartat,

Tayangan+Infotainment+tentang+Poli gami+Kebablasan-.phpx tanggal 19 April 2013.

Radikun. (1999). Gembira dan Prihatin karena Tayangan Televisi. Jurnal Teknodik, (2)

Raghavan, P. (2008). Family, Politics and Popular Television: An Ethnographic Study of Viewing an Indian Serial Melodrama. Disertasi. School of Communication, Culture and Languages Faculty of Arts, Education and Human Development Victoria University. Diunduh dari: http://vuir.vu.edu.au/ 1410/1/raghavan.pdf

Shrum, L. J., \& Bischak, V. D. (2001). Mainstreaming, resonance, and impersonal impact: Testing moderators of the cultivation effect for estimates of crime risk. Human Communication Research, 27(2), 187-215.

Shrum, L. J., Thomas C. O'Guinn, Richard J. S., \& Ronald J. F. (1991).“Processes and Effects in the Construction of
Normative Consumer Beliefs: The Role of Television," in Advances in Consumer Research, Vol. 18, eds. R. H. Holman \& M. R. Solomon, Provo, Utah: Association for Consumer Research, 755-763.

Sukarelawati. (2009). Persepsi Pemirsa tentang Tayangan Infotainment Di Televisi: Kasus Pemirsa Di Bojong Gede, Bogor. (Tesis tidak dipublikasikan). Bogor: Institut Pertanian Bogor.

Tempo. (2013, 6 Maret). Acara TV Paling Digemari Penonton Indonesia. Diunduh dari: http://www.tempo.co/read/news/ 2013/03/06/090465467/Acara-TV-IniPaling-Digemari-Penonton-Indonesia tanggal 19 April 2013.

The CCS 2010 Conference and The 4th International Conference on Digital Communication, CHIA-YI. (2010). "Impact of soap opera 'Moonlight Resonance' on the Perception of Marriage, Justice, Moral Values and Family of Teenagers in Hong Kong". Taiwan, July 3-5.

Vice, S. (2010). Cynicism and Morality. Ethic Theory Moral Prac. Diunduh dari: http://www.ru.ac.za/media/rhodesuni versity/content/documents/philosophy /Cynicism\%20and\%20Morality.pdf

Vonderen, K. E. V., \& Kinnally, W. (2012). Media Effects on Body Image: Examining Media Exposure in the Broader Context of Internal and Other Social Factors. American Communication Journal, 14(2).

Wert, S. R., \& Salovey, S. (2004). A Social Comparison Account of Gossip. Review of General Psychology, 8(2), 122137. 